\title{
窒化アルミニウムの遮光化及び熱伝導性に及ぼす金属不純物の効果
}

\author{
柊平＼cjkstart啓·仲田博彦* \\ 住友電気工業(株)研究企画部，554-0024 大阪市此花区島屋 1-1-3 \\ *住友電気工業(株) エレクトロニクス・材料研究所, 664-0016 伊丹市昆陽北 1-1-1
}

\section{Effect of Metal Impurities on Shading and Thermal Conductivity of Aluminum Nitride}

\begin{abstract}
Akira KUIBIRA and Hirohiko NAKATA*
$R \& D$ Planning Department, Sumitomo Electric Industries, Ltd.,1-1-3, Shimaya, Konohana-ku, Osaka-shi 554-0024

${ }^{*}$ Electronics \& Materials $R \& D$ Laboratories, Sumitomo Electric Industries, Ltd., 1-1-1, Koya-kita, Itami-shi 664-0016

Because aluminum nitride (AIN) has a high thermal conductivity and a high electrical resistivity, it is used for substrates and packaging for high power or high density circuits. Silicon chips need to be protected from faults caused by exposure to ultra-violet rays. AIN packaging and substrates have to be shaded for UV protection. The characteristics of AIN are influenced by a number of factors. Specifically, metallic impurities affect the shading and thermal conductivity, and are particularly easily mixed with AIN as minerals or solutions during processing. It is very important to understand how metallic impurities influence the characteristics of AIN, and either refine processing to eliminate such effects, or add metal to achieve the desired industrial characteristics. Iron ( $F e)$, silicon $(\mathrm{Si})$, magnesium $(\mathrm{Mg})$, and titanium $(\mathrm{Ti})$ are metals that are easily mixed, so it is important to understand their influence. The metallic impurities $\mathrm{Fe}, \mathrm{Si}, \mathrm{Mg}$, and $\mathrm{Ti}$ were added to raw powder $\mathrm{AIN}$ and uniformly distributed at a molecular level. The powder was sintered and tested for any effects on shading or reduction in thermal conductivity. Some Ti compounds were found at the grain boundaries, but these did not reduce the AIN thermal conductivity and provided efficient shading. In contrast, Si and $\mathrm{Mg}$ compounds were not found at the grain boundaries but formed solid solutions in the AIN grains, so they significantly reduced the AIN thermal conductivity and provided no shading. The effect of Fe was intermediate between that of $\mathrm{Ti}$ and $\mathrm{Si}$ and was characterized by its tendency to form solid metal ion solutions in the AIN grains.
\end{abstract}

[Received February 21, 2005; Accepted January 19, 2006]

Key-words : Aluminum nitride, Metal impurity, Shading, Thermal conductivity

\section{1. 緒 言}

産業電子機器等の高速処理, 小型化の要請に伴う半導体デバ イスの高集積, 高密度化のために単位体積当たりの発熱量が多 くなり，半導体素子の信頼性に大きな影響を及ぼすようになっ てきている．通常の電子機器には酸化アルミニウム $\left(\mathrm{Al}_{2} \mathrm{O}_{3}\right)$ が用いられているが，熱伝導率が $20 \mathrm{~W} / \mathrm{m} \cdot \mathrm{K}$ 程度と低く十分 な放熱ができない. また $170 \mathrm{~W} / \mathrm{m} \cdot \mathrm{K}$ と高熱伝導率のベリリア （BeO）は毒性を有するという問題がある.この他, 高集積化 によりチップサイズが大きくなると, 熱膨張率がシリコン $(\mathrm{Si})$ と異なる場合, 熱応力による破壞を生じ素子としての信頼性の 低下を引き起こす.

高電力や, 高集積半導体素子のパッケージ用材料として要求 される性能をまとめると次のようになる.

(1)熱伝導性が良い，(2)電気絶縁性が優れている，(3)熱膨張率 が Si と同程度である, (4)誘電率や誘電損失が小さい, (5)機械 的強度が大きい, (6)メタライズ性が優れている, (7)法精度や 表面平滑性が良い, (8)加工性が良い, (9)化学的に安定である, (10)放射性不純物が少ない, (11)耐熱性がある, (12)低コストであ る、この中でも熱伝導性は特に重要な特性である. 窒化アルミ ニウム (AlN) はこれらの要件を満たす材料として優れた材料 である ${ }^{1)}$.

また, EPROM 等では外部から入ってくる光によってチップ が誤動作しないように材料の遮光性が求められている2).

AlN の特性を制御するためには，焼結による緻密化，原料粉 体中及び工程内における不純物量の低減, 粒界相制御といった 要因が重要である.この中でも不純物金属は微細構造（AlN 粒
内や粒界構造）に大きく影響し，熱伝導特性を左右する ${ }^{3), 4)}$. そこで本研究では, AlN 粉末に不純物金属を添加して, 金属種 の固溶や分散状態が熱伝導性と光学特性に及ぼす影響の違いを 明らかにする.

\section{2. 実験方法}

原料粉体として, AlN には不純物含有量の少ないトクヤマ 製, Fグレードを用いた (酸素 : 0.81 mass\%, シリコン $(\mathrm{Si}): 10$ $\mathrm{ppm}$, 鉄 $(\mathrm{Fe}): 5 \mathrm{ppm})$. 焼結助剂には三菱化成製 $\mathrm{Y}_{2} \mathrm{O}_{3}$ （純度 99.5\%）を使用した。

不純物金属のうち，原料粉末中に含まれやすい，あるいは八 ンドリング中に混入しやすく，特性に影響を及ぼすと考えられ る, 鉄 $(\mathrm{Fe})$, シリコン $(\mathrm{Si})$, チタン $(\mathrm{Ti})$, マグネシウム $(\mathrm{Mg})$ を選択し，有機金属塩あるいは無機塩の形で均一に添加して焼 結体を作製し，その効果を調査した。

それぞれの金属添加用試薬として，すべて高純度化学製の試 薬を用い, $\mathrm{Fe}$ は純度 $99 \%$ の $\mathrm{Fe}(\mathrm{NO})_{3} \cdot 9 \mathrm{H}_{2} \mathrm{O}, \mathrm{Si}$ は純度 $99.9999 \%$ の $\mathrm{Si}\left(\mathrm{OC}_{2} \mathrm{H}_{5}\right)_{4}, \mathrm{Ti}$ は純度 $99.999 \%$ の $\mathrm{Ti}\left(\mathrm{OC}_{2} \mathrm{H}_{5}\right)_{4}, \mathrm{Mg}$ は純度 99.9\%の $\mathrm{Mg}\left(\mathrm{OC}_{2} \mathrm{H}_{5}\right)_{2}$ を使用した。

添加金属試薬のエタノール溶液を所定の量, 酸化イットリウ 厶 $\left(\mathrm{Y}_{2} \mathrm{O}_{3}\right)$ 粉末を $\mathrm{AlN}$ 粉末に対し 1 mass\%あるいは 5 mass $\%$ になるように配合した. 全量で $250 \mathrm{~g}$ とした粉末中に投入した. $1000 \mathrm{ml}$ のポリエチレンポットにナイロンボール（鉄芯入り） $1 \mathrm{~kg}$ とともに入れ, 溶媒にエタノール $400 \mathrm{ml}$ を用いてボールミ ル法により $24 \mathrm{~h}$ 混合した.

混合後, ナイロン製100メッシュ篩を通過させて, 混合時の 


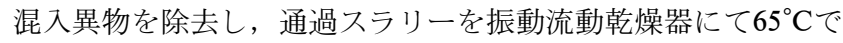
真空乾燥を行った. その後ナイロン製100メッシュにて粉体を ふるい分けして顆粒化した.

成形には，一軸金型プレスを用い，1 枚当たり $40 \mathrm{~g} の 50 \times 60$ $\mathrm{mm}$ の平板に成形した。成形圧力は $10 \mathrm{MPa}$ とし, 更に, 300 $\mathrm{MPa}$ で冷間静水圧プレス (CIP) 成形した.

成形体は内壁を窒化ホウ素（BN）粉末で被覆した AlN 容器 中にセットし，これを更に内壁を $\mathrm{BN}$ 粉末で被覆したカーボン

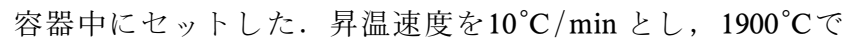
$3 \mathrm{~h}$, 窒素 $\left(\mathrm{N}_{2}\right)$ ガス圧 $0.2 \mathrm{MPa}$ で焼結した.

焼結体の密度はアルキメデス法により測定した。焼結体中に 残留した不純物金属含有量は, ICP 発光分光分析装置を用いて 分析した. その分析用の試料は, AlN 焼結体を粉砕して0.1000 g を精秤し，炭酸ナトリウム $2 \mathrm{~g}$ とホウ酸 $1 \mathrm{~g}$ を添加して白金る つぼに入れ, $1000^{\circ} \mathrm{C} て ゙ 1 \mathrm{~h}$ 保持して溶解し，その後塩酸で抽出 後に蒸留水希釈して作製した. 熱伝導率は熱定数測定装置（理 学電機, LF/TCM-FA8510B) で測定した。焼結体組織は走査 型電子顕微鏡（SEM；日立製作所製，S-800）及び透過型電子 顕微鏡（TEM；日本電子製，JEM-4000FX）で観察し，不純 物偏析解析にはSEM に取付けた EDS 及び電子線回折を用い た。また焼結体の遮光性は, 焼結体を\#4000 mesh まで研磨 後, ミノルタ製, 分光測色計 CM-2022 にて明度を測定した. これは理想的な黒の明度を 0 , 理想的な白の明度を10とし，そ の明るさの知覚が等歩度となるように 10 分割して測定表示した ものである.

\section{3. 結果及び考察}

\section{1 焼結体遮光化に及ぼす微細組織の効果}

各不純物を添加して作製した焼結体の明度を $\mathrm{Y}_{2} \mathrm{O}_{3}$ 添加量 1 mass\%で比較した．各金属添加焼結体と明度の関係を図 1 に 示す.

金属無添加焼結体は明度が7.0であった． Si や Mg 添加焼結 体は添加量を増やしても無添加品とほぼ同じ色調であり, 310 ppm Si 添加焼結体の明度が7.0, 940 ppm Mg 添加焼結体の明度 が7.1であった。 一方, Fe, Ti は添加量の増加とともに黒色化 し, 黒色化への効果は, Ti が最も著しかった. $912 \mathrm{ppm} \mathrm{Fe}$ 添 加焼結体の明度が5.1で, $960 \mathrm{ppm} \mathrm{Ti}$ 添加焼結体の明度が4.0で あった. $\mathrm{Y}_{2} \mathrm{O}_{3}$ の添加量で比較すると, 添加量が 1 mass\%の焼 結体の方がより透光性を示し, 添加量が 5 mass\%の焼結体は乳 白色に失透した.

図 1 に示すように，黒色化の度合いは $\mathrm{Y}_{2} \mathrm{O}_{3} 1$ mass\%の方が 5 mass \%より著しかった。 Fe や Ti の金属量が同程度（1000 ppm）の焼結体で, $\mathrm{Y}_{2} \mathrm{O}_{3}$ の添加量の効果を比較すると, $\mathrm{Fe}$ で は, $\mathrm{Y}_{2} \mathrm{O}_{3}$ が 1 mass\%の焼結体の明度は5.1で， 5 mass\%の焼結 体の明度は 5.7 であった。一方， $\mathrm{Ti}$ では， $\mathrm{Y}_{2} \mathrm{O}_{3}$ が 1 mass\%の焼 結体は4.0で， 5 mass\%の焼結体は4.4であった。

各不純物を添加した AlN 焼結体の粒径や微構造は無添加の 焼結体と大差はなかった。

各焼結体中の不純物金属の分布を，SEM-EDS で面分析した 結果を図 2 に示す。Ti は粒界に多数偏析しているのが確認され た. $\mathrm{Fe}$ の局地的な偏析は見られた. 一方, $\mathrm{Si}, \mathrm{Mg}$ の偏析は本 実験での SEM や TEM 観察では確認できなかった.

偏析状態を, 更に詳しく調べるために, Ti と Fe の添加焼結 体を TEM-電子線回折で解析した. 結果を図 3 に示す. Ti 添加 焼結体では, $\mathrm{Ti}$ の偏析は各所に見られた。この偏析物は $\mathrm{AlN}$ 相にも粒界相にもほとんど需れていない。この偏析物は電子線 回折解析の結果, $\mathrm{TiN}_{1-x} \mathrm{O}_{x}$ であった $(x=0 \sim 1)$.

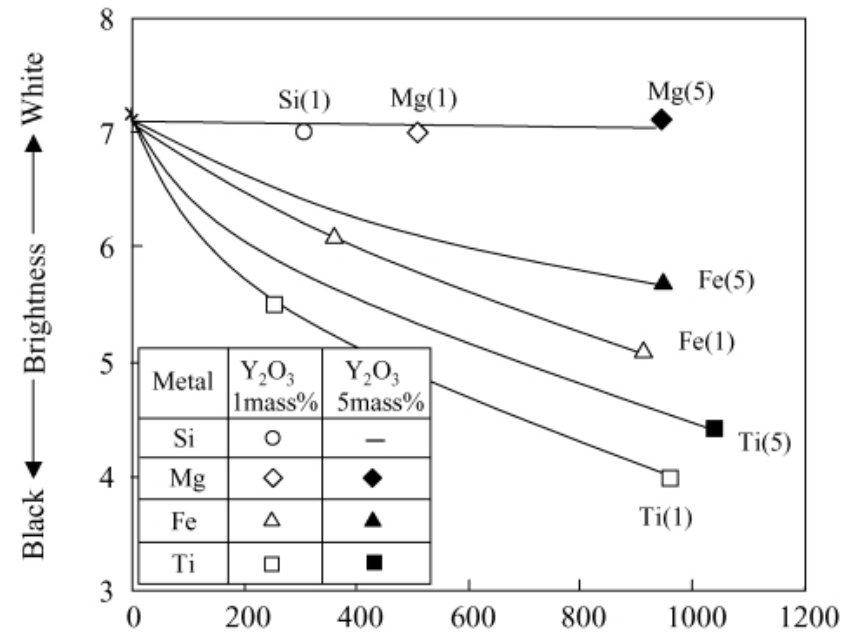

Metal impurities in AlN sintered body / ppm

Fig. 1. Brightness of sintered AlN with metal impurities.

$\mathrm{Fe}$ 添加焼結体では偏析量は Ti に比べて微量であり, Y$\mathrm{Al}-\mathrm{O}$ 粒界相との界面がやや不明瞭であった。この偏析物は電 子線回折の結果 $\mathrm{Fe}_{2} \mathrm{O}_{3}$ であった.

次に各試料の遮光性について考えてみる. $\mathrm{Y}_{2} \mathrm{O}_{3}$ のみを 1 mass\%添加した焼結体と 5 mass\%添加した焼結体を比較する と, 1 mass\%添加では透光性を示し, 5 mass\%添加では乳白色 となり失透していた。一般に $\mathrm{AlN}$ は焼結助剤に $\mathrm{Y}_{2} \mathrm{O}_{3}$ を用いて 焼結しているが，これは焼結体中で，Y-Al-O 化合物として三 重点に偏析する. $\mathrm{Y}-\mathrm{Al}-\mathrm{O}$ 化合物は絶縁材料であり, エネル ギーギャップが広く, 可視光の吸収は起こらないと考えられ る.したがって遮光性を示さない, 一方, Y-Al-O 化合物の屈 折率は AINの屈折率と大きく異なることにより, 両者の界面 でほとんどの光子が散乱する．このため $\mathrm{Y}_{2} \mathrm{O}_{3}$ を多く添加した 焼結体の方が, 白く失透したと考えられる.

$\mathrm{Ti}$ 添加焼結体中で, $\mathrm{Ti}$ は $\mathrm{TiN}_{1-x} \mathrm{O}_{x}(x=0 \sim 1)$ の形で三重点 に多量に偏析していた. $\mathrm{TiN}_{1-x} \mathrm{O}_{x}$ のエネルギーギャップは文 献に見出せないが， $\mathrm{TiO}_{2}$ の $3.03 \mathrm{eV}$ に近いエネルギーギャップ を有すると考えられ, 可視光を効果的に吸収するため, 遮光性 が著しかったと考えられる

$\mathrm{Fe}$ 添加焼結体中で, $\mathrm{Fe}$ は極微量の $\mathrm{Fe}_{2} \mathrm{O}_{3}$ 相として三重点に 存在していた. $\mathrm{Fe}_{2} \mathrm{O}_{3}$ のエネルギーギャップは $2.2 \mathrm{eV}$ 程度であ り可視光を吸収しうる. また， $\mathrm{Y}_{2} \mathrm{O}_{3}$ の添加量を 1 mass \%から 5 mass\%に増加させると, $\mathrm{Fe}$ 含有量がほぼ同一でも遮光化の度 合いが弱まった.これは, $\mathrm{Y}_{2} \mathrm{O}_{3}$ の添加量が多いほど, $\mathrm{Fe}$ や $\mathrm{Ti}$ の $\mathrm{Y}_{2} \mathrm{O}_{3}$ との反応が増加し, YIG (Yttrium-Iron-Garnet) や $\mathrm{Y}_{2} \mathrm{TiO}_{5}$, $\mathrm{Y}_{2} \mathrm{Ti}_{2} \mathrm{O}_{7}$ 等のエネルギーギャップの広い化合物に変化したため と考えられる.

\section{2 熱伝導性}

図 4 に, $\mathrm{Y}_{2} \mathrm{O}_{3} 5$ mass\%添加試料に抢ける, 不純物金属の熱 伝導性に及ぼす効果について示す，いずれの不純物においても 添加量の増加とともに熱伝導性は低下し, 添加量に対する低下 率は徐々に減少した.

$\mathrm{Si}, \mathrm{Mg}$ 添加焼結体では $500 \mathrm{ppm}$ の添加で $45 \mathrm{~W} / \mathrm{m} \cdot \mathrm{K}$ に減少し たが, Ti 添加焼結体では, $1000 \mathrm{ppm}$ の添加でも $10 \mathrm{~W} / \mathrm{m} \cdot \mathrm{K}$ の 減少であった. $\mathrm{Fe}$ 添加体は両者の中間の減少量であった.

熱伝導性の低下は，不純物金属の AlN 相中への固溶と AlN 相内の結晶格子の乱れにより引き起こされると考えられる ${ }^{3)}$. 

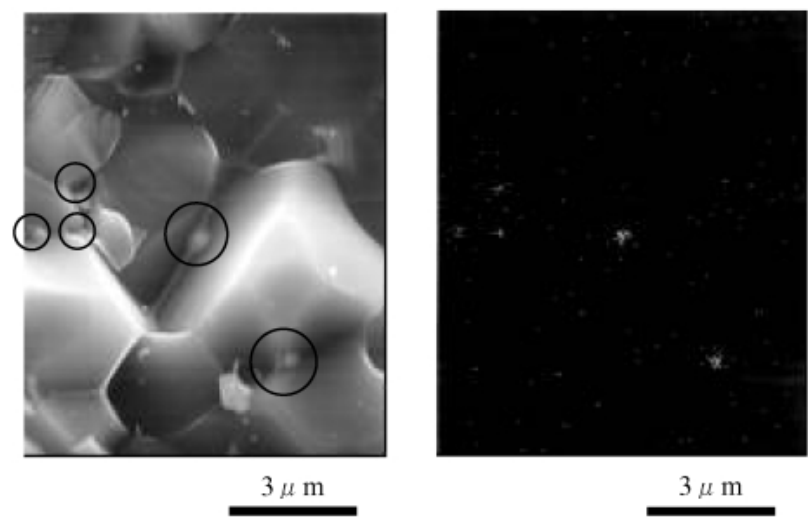

(a)
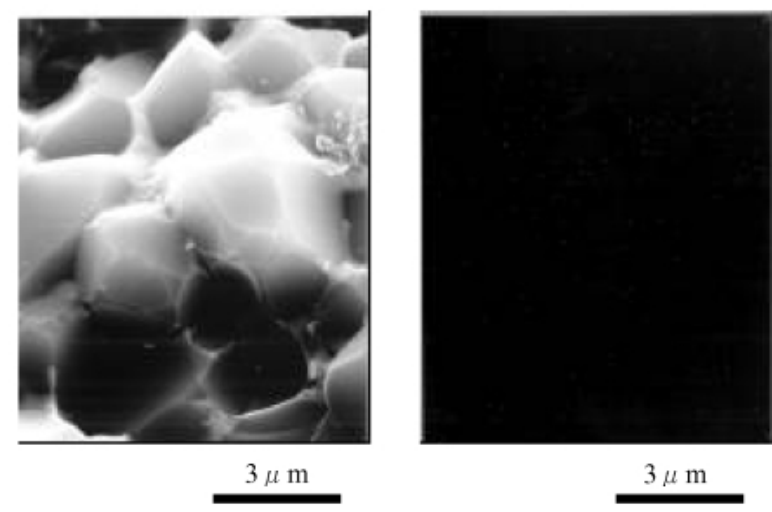

(c)
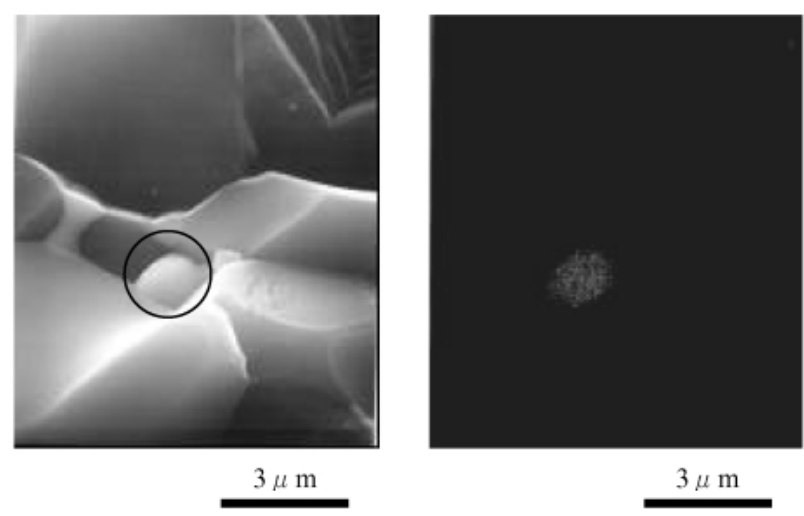

(b)
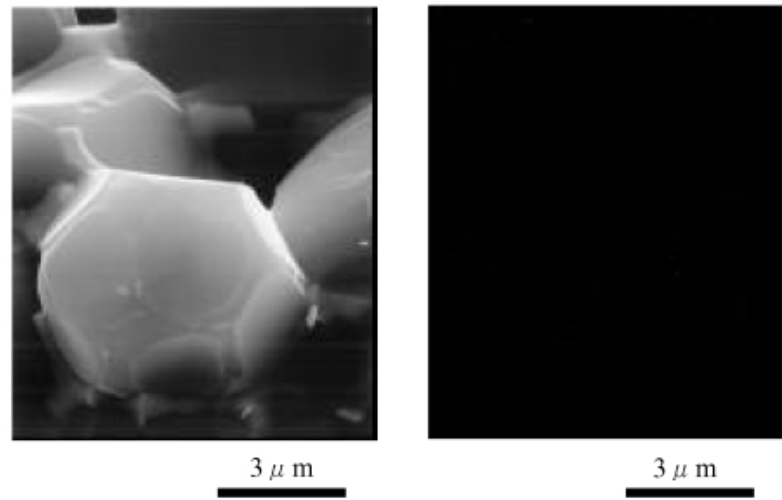

(d)

Fig. 2. SEM image and EDS of (a) Ti in sintered AlN (960 ppm Ti), (b) Fe in sintered AlN (912 ppm Fe), (c) Si in sintered AlN (310 ppm Si), (d) $\mathrm{Mg}$ in sintered $\mathrm{AlN}(940 \mathrm{ppm} \mathrm{Mg})$.

この金属元素による熱伝導性低下の差は，AIN 相への金属元素 の固溶量の差に起因すると考えられる.

$\mathrm{AlN}$ 焼結体中の熱伝導は，フォノン伝導が支配的である. Al と $\mathrm{N}$ の結合を介してフォノンが格子振動として伝わっていく ため，不純物の混入に伴う結合分断や，不規則化により，フォ ハン伝導が阻害されて熱伝導性は低下する，得られた実験結果 をもとに，各金属が熱伝導性に及ぼす影響を以下に議論した。

高純度の AlN 焼結体ではフォノンは AlN 粒子から AlN 粒子 へ比較的散乱されずに伝わっていく. $\mathrm{Y}^{3+}$ や $\mathrm{Ti}^{3+}$ は, AlN 相 に固溶せず，Y-Al-O や $\mathrm{TiN}_{1-x} \mathrm{O}_{x}$ として粒界の三重点に押し 込められた状態で存在する（図 $2(\mathrm{a})$ )。 そのためフォノン散乱 は少なく，高い熱伝導性が維持される。しかし $\mathrm{Si}^{4+} や \mathrm{Mg}^{2+}$ は AlN 相へ容易に固溶する ${ }^{6)}$ 。このとき, 電気的中性を保つため に, $\mathrm{Al}^{3+}$ や $\mathrm{N}^{3-}$ が抜けて格子欠陥が生成し, 熱伝導性は大幅 に低下する ${ }^{3)} . \mathrm{Fe}^{3+}$ は固溶しやすさが両者の中程度であり, 極 微量の固溶が生じていると考えられる.

不純物金属の粒内への固溶へのしやすさは，(1)Alの sp3 混 成軌道による正四面体構造と同じ電子構造を取ること, (2) AlN との反応生成物が安定であること, (3)金属のイオン半径が $\mathrm{Al}^{3+}$ と近いことが考えられる.

$\mathrm{Si}$ と $\mathrm{Mg}$ は $\mathrm{Al}$ と同じ外殼電子構造を有し, sp3 混成軌道に よる正四面体構造を取ると考えられる7)。それらが窒素 $(\mathrm{N})$ の $\mathrm{sp} 3$ 混成軌道による正四面体構造と共有結合を生じると, $\mathrm{Mg}$ 置換では電子が 1 個不足し, $\mathrm{Si}$ 置換では電子が 1 個余る. この電子の過不足を補償するために， $\mathrm{N}^{3-}$ あるいは $\mathrm{Al}^{3+}$ が抜け
るため, 結合が切れてフォノン伝導が妨げられる.

$\mathrm{Fe}$ や $\mathrm{Ti}$ は最外殼電子が $3 \mathrm{~d}$ 殼と $4 \mathrm{~s}$ 殼, $\mathrm{Y}$ は $4 \mathrm{~d}$ 殼と $5 \mathrm{~s}$ 殼で あり, $\mathrm{Al}$ と置換しにくいと考えられる. 更にイオン半径で比 較すると, $\mathrm{Ti}^{4+}$ と $\mathrm{Y}^{3+}$ のイオン半径はそれぞれ $0.06 \mathrm{~nm}$ と 0.088 $\mathrm{nm}$ であり, $\mathrm{Al}^{3+}$ イオン半径の $0.045 \mathrm{~nm}$ との差が大きい.この ためほとんど固溶しないと思われる. 一方 $\mathrm{Fe}^{3+}$ のイオン半径 は0.051 nm と $\mathrm{Al}^{3+}$ に近いため, $\mathrm{Ti}$ や $\mathrm{Y}$ より固溶しやすいと考 えられる7).

\section{4. 結 論}

金属不純物が AlN の焼結体の微構造, 遮光化, 熱伝導性に 及ぼす影響を検討するため, 各金属 $(\mathrm{Si}, \mathrm{Mg}, \mathrm{Fe}, \mathrm{Ti})$ が均一に 添加された焼結体を作製して評価したところ，以下のことが明 らかになった。

（1）焼結助剂としての $\mathrm{Y}_{2} \mathrm{O}_{3}$ の量は 5 mass\%より 1 mass\% の方が遮光化の効果は著しかった，

（2） $\mathrm{Ti}$ 添加焼結体は最も遮光性が高く，熱伝導性の低下は 小さかった。逆に $\mathrm{Si}, \mathrm{Mg}$ 添加焼結体はほとんど遮光化しない が，熱伝導性は大きく低下した。

（3） $\mathrm{Ti}$ 添加焼結体では粒界に多くの $\mathrm{TiN}_{1-x} \mathrm{O}_{x}$ の偏析が見 られ, $\mathrm{Fe}$ 添加焼結体では微量の $\mathrm{Fe}_{2} \mathrm{O}_{3}$ 偏析が見られた。一方 $\mathrm{Si}, \mathrm{Mg}$ 添加焼結体では偏析物は検出されなかった。 AlN 焼結 体の遮光化の主な原因は, これらの偏析物のエネルギーギャッ プの大きさであると考えられる.

（4）不純物金属が AlN 相へ固溶して熱伝導性低下を引き起 


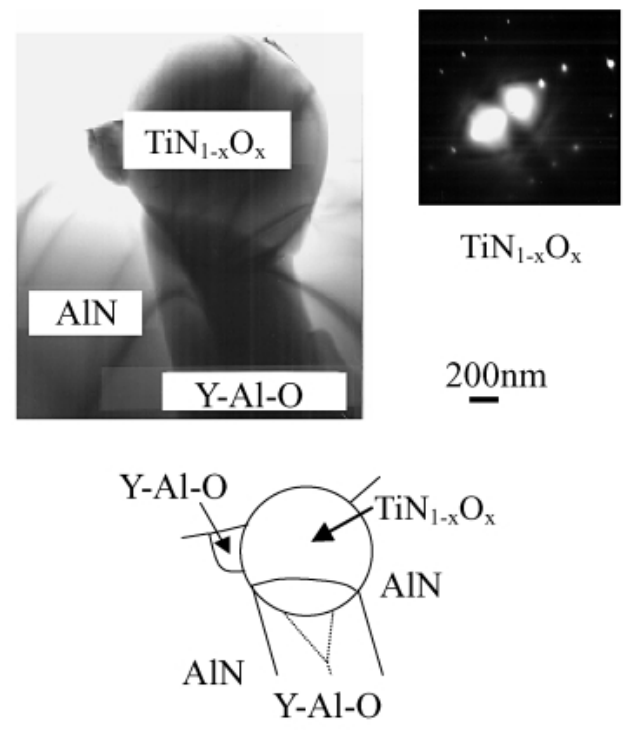

(a)
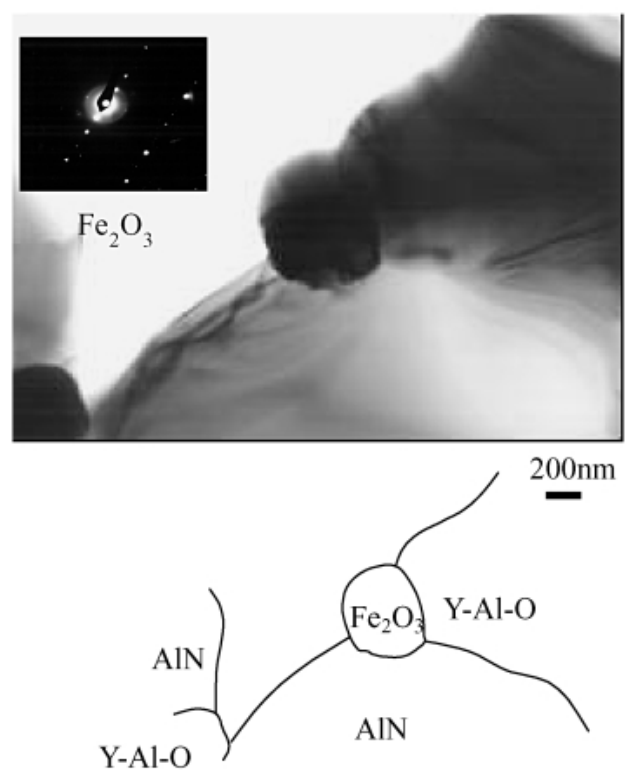

(b)

Fig. 3. TEM image and (a) ED of Ti in sintered AlN (960 ppm Ti), and (b) EDS of Fe in sintered AlN (912 ppm Fe).

こすためには, (1) Al と同じ電子構造を取ること, (2) AlN 相と の反応生成物が安定であること, (3)金属のイオン半径が $\mathrm{Al}^{3+}$

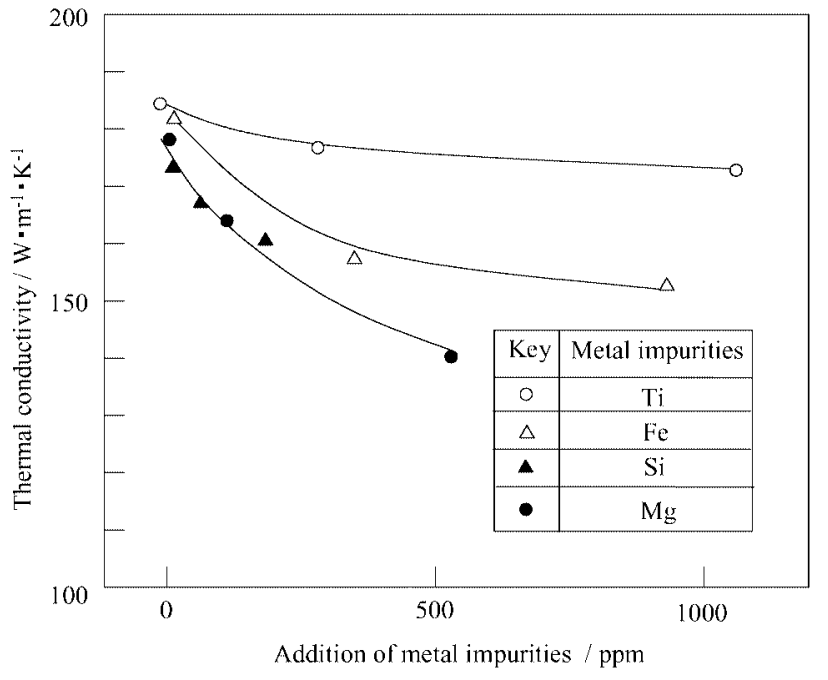

Fig. 4. Thermal conductivity of sintered AlN with added metal impurities.

と近いことのいずれかが考えられる.Si は(1)と(2)を満たし， $\mathrm{Mg}$ は(1)を満たすため容易に固溶する. Fe は(3)を満たすことで 若干固溶する. しかし Ti と Y はいずれの条件も満たさず固溶 しないと考えられる.

\section{References}

1) Hotta, A., Ueno, F. and Tsuge, A., Toshiba Review, Vol. 44, pp. 616-618 (1989) [in Japanese].

2) Kasori, M., Ueno, F., Horiguchi, A. and Goto, Y., Proceedings of Fall Meeting Ceram. Soc. Japan (1990) pp. 504-504 [in Japanese].

3) Kuramoto, N., Taniguchi, H., Numata, Y. and Aso, I., J. Ceram. Soc. Japan (Yogyo-Kyokai-Shi), Vol. 93, pp. 517-521 (1985) [in Japanese].

4) Sakuma, K., Okada, A. and Kawamoto, H., J. Mater. Synthesis and Processing, Vol. 6, pp. 315-321 (1998).

5) Uno, R., Morita, A., Tsuya, N. and Yamashita, J., "Dai 5 Han Kotai Butsurigaku Nyumon Jou,” Maruzen (1983) pp. 195-198 [in Japanese].

6) Kasori, M., Ueno, F. and Tsuge, A., J. Am. Ceram. Soc., Vol. 77, pp. 1991-2001 (1994).

7) Uno, R., Morita, A., Tsuya, N. and Yamashita, J., "Dai 5 Han Kotai Butsurigaku Nyumon Jou,” Maruzen (1983) pp. $92-96$ [in Japanese]. 